\title{
Anxiety in pregnancy: prevalence and associated factors*
}

\author{
Ansiedade na gravidez: prevalência e fatores associados \\ Ansiedad en el embarazo: prevalencia y factores asociados
}

Mônica Maria de Jesus Silva', Denismar Alves Nogueira² ${ }^{2}$ Maria José Clapis ${ }^{3}$, Eliana Peres Rocha Carvalho Leite ${ }^{4}$

How to cite this article:

Silva MMJ, Nogueira DA, Clapis MJ, Leite EPRC. Anxiety in pregnancy: prevalence and associated factors. Rev Esc Enferm USP. 2017;51:e03253. DOI: http:// dx.doi.org/10.1590/S1980-220X2016048003253

*Extracted from the dissertation "Avaliação da ansiedade e depressão na gravidez",

Programa de Pós-graduação em Enfermagem, Universidade Federal de Alfenas, 2014.

${ }^{1}$ Universidade de São Paulo, Escola de Enfermagem de Ribeirão Preto,

Programa de Enfermagem em Saúde Pública, Ribeirão Preto, SP, Brazil.

${ }^{2}$ Universidade Federal de Alfenas, Instituto de Ciências Exatas, Alfenas, MG, Brazil.

${ }^{3}$ Universidade de São Paulo, Escola de Enfermagem de Ribeirão Preto, Ribeirão Preto, SP, Brazil.

${ }^{4}$ Universidade Federal de Alfenas, Escola de Enfermagem, Alfenas, MG, Brazil.

\section{ABSTRACT}

Objective: Evaluating the occurrence of anxiety in pregnant women and the factors associated with its occurrence; comparing the presence of anxiety in each gestational trimester. Method: A descriptive, correlational cross-sectional study. Data were collected from January to May 2013 using the Hospital Anxiety Subscale and a form composed of socioeconomic characterization; gestational anamnesis; life-changing habits and events; preexisting conditions and interpersonal relationships. Results: A total of 209 pregnant women from a municipality in the south of Minas Gerais, Brazil, participated in the study. Anxiety was present in $26.8 \%$ of the pregnant women, being more frequent in the third trimester $(42.9 \%)$. Occupation $(p=0.04)$, complications in previous pregnancies $(\mathrm{p}=0.00)$, history of miscarriage risk of preterm birth $(\mathrm{p}=0.05)$, maternal desire regarding the pregnancy $(p=0.01)$, number of abortions $(p=0.02)$, number of cigarettes smoked daily $(p=0.00)$ and drug use $(p=0.01)$ were statistically associated with the occurrence of anxiety during pregnancy. Conclusion: Anxiety occurred frequently during pregnancy. Understanding the factors associated with its occurrence allows for elaborating preventive measures in prenatal care.

DESCRIPTORS

Pregnancy; Anxiety; Risk Factors; Obstetric Nursing; Prenatal Care. 


\section{INTRODUCTION}

Pregnancy is a period in which physiological, psychic, hormonal and social changes are present, increasing the risk of emotional suffering and psychiatric morbidity in this stage of a woman's life ${ }^{(1)}$.

Some women may experience pregnancy as a source of happiness, satisfaction and self-fulfillment. Others, however, may experience during this period changes in their mental health, such as the development of anxiety ${ }^{(2)}$.

Evidence on prenatal anxiety is still relatively limited when compared to prenatal depression. Although maternal anxiety indexes during pregnancy are heterogeneous, anxiety symptoms and disorders are common in the perinatal period $^{(3-4)}$, and the symptoms may range from mild to severe ${ }^{(5)}$.

National and international studies point to variable anxiety indexes around 23\% in a study conducted in Alberta, Canada $^{(6)}, 15.6 \%$ in a study carried out in Germany ${ }^{(7)}$ and $49 \%$ in Pakistan ${ }^{(8)}$.

The evidence suggests that the likelihood of anxiety during pregnancy increases in cases of psychiatric comorbidity, stressful events ${ }^{(6,9)}$, social disadvantage, history of abortion, fetal loss, preterm delivery or early neonatal loss ${ }^{(8,10)}$, previous history of mental illness or a history of psychiatric treatment during an earlier pregnancy or throughout life $f^{(9,11)}$.

Considering the belief among many societies that the psychological state of the mother can affect the child in her womb, anxiety disorder is considered one of the risk factors in pregnancy development, since its onset may compromise the fetus in being associated with negative neonatal outcomes, such as prematurity, low birth weight ${ }^{(12)}$, lower Apgar scores, fetal development deficit, in addition to lasting effects on the physical and psychological development of the child ${ }^{(13)}$ and obstetric complications, such as vaginal bleeding and the risk of abortion ${ }^{(3)}$.

As well as prenatal depression, anxiety in this period is one of the major risk factors for postpartum depression ${ }^{(9)}$.

Despite its harmful impact on pregnancy, women's mental health in prenatal care has sometimes received less attention compared to maternal emotional state in the postpartum period ${ }^{(5)}$; investigations on the occurrence of anxiety during pregnancy and its associated factors are scarce ${ }^{(6)}$.

Understanding its occurrence as well as the factors associated with prenatal anxiety may help in developing screening strategies to identify risk groups of women in need of intervention during pregnancy. Thus, the objectives of this study were: to evaluate the occurrence of anxiety in pregnant women; to evaluate possible associated factors among the measures of anxiety in pregnant women, such as socioeconomic, demographic, obstetric variables, life habits, significant life events and interpersonal relationships; and to compare the presence of anxiety in each gestational trimester.

\section{METHOD}

\section{Study Design}

A cross-sectional descriptive and correlational study carried out in Primary Health Care Units that offer prenatal care through the Unified Health System (Sistema Único de Saúde - SUS) in the South of Minas Gerais state, Brazil.

\section{Population AND SAMPLE}

The study population consisted of pregnant women undergoing prenatal care at the Primary Health Care Units. A total of 209 pregnant women were randomly selected. In order to calculate sample size, a prevalence of $50 \%$, a confidence level of $95 \%$, a margin of error of $5 \%$ and an estimate of pregnant women who had prenatal care in the previous year of 450 pregnant women were considered. Inclusion criterion considered for selection of the participants was being aged equal to or greater than 18 years. Exclusion criteria were: current diagnosis of anxiety disorders and/or other mental disorders; current use of anxiolytic drug and/or other psychotropic drugs; having previously participated in the study during gestation in the pilot study. Participants were included in the sample through a random draw that used the numbers on the records of pregnant women that would be attending the Health Unit on the data collection day. Thus, half of the pregnant women that met the defined eligibility criteria were randomly selected. These randomly selected pregnant women were later invited to participate in the study while waiting for their prenatal consultation in the waiting room.

\section{Data Collection instrument}

Two instruments were applied for data collection; the Hospital Anxiety Subscale (HADS-A) translated and validated for the Portuguese language version ${ }^{(14)}$, and another for sample characterization.

The instrument for sample characterization was composed of objective questions designed by the researchers, containing sociodemographic and obstetric questions, in addition to referring to habits and life events, interpersonal relationships and preexisting pathologies.

The Hospital Anxiety Subscale (HADS-A) is an instrument for assessing anxiety through self-reporting. It integrates the Hospital Anxiety and Depression Scale (HADS), which has 14 multiple choice questions divided into two domains; one regarding anxiety (HADS-A) and another depression (HADS-D). Each domain has seven items, and each question has a score ranging from zero to three, with the overall score on each subscale ranging from zero to 21 points. For interpretation of anxiety, the following cut-off points established in the Brazilian adaptation of the subscale were used: 0 to 8 - no anxiety; equal to or greater than $9-$ having anxiety ${ }^{(15-16)}$.

\section{Appearance AND CONTENT ANALYSIS, AND PILOT TEST}

A validation of the appearance and content of the sample characterization instrument was performed prior to data collection. This procedure was performed with the objective of refining the characteristics expressed in accordance with the study theme.

For this validation process, the instrument under analysis was sent together with an evaluation form containing questions related to its presentation, ease of reading, 
clarity and content, as well as suggestions for changes of the items, to a group of five judges (researchers on the subject of Maternal and Child Health and/or Anxiety and Depression) with experience in constructing and validating research instruments.

The judges suggested language correction to make the points clearer, changes regarding the structure of some questions, along with insertion/inclusion and combination of other questions. The suggestions of all the judges were considered relevant, accepted and the adjustments were made in the instrument.

In order to guarantee the participants' understanding, the instrument and the adapted Portuguese version of HADS-A were submitted to a pilot test after analysis through an interview with 20 pregnant women who were in prenatal care consultations in the Health Units selected for the study, and who were subsequently excluded from the final sample. The pregnant women were randomly selected while awaiting prenatal care.

The result demonstrated that the instrument is easily understood by the pregnant population, without the need to change its wording or format.

\section{Data Collection}

Data collection was performed by one of the researchers through the instruments from January to May 2013, after approval by the Research Ethics Committee of the Universidade Federal de Alfenas, with protocol number 113.129, in accordance with the guidelines of Resolution 196/96 of the National Health Council/Ministry of Health.

For its completion, pregnant women were brought to a reserved and secure room in the Health Units, where they were introduced to the Free and Informed Consent Form and informed about the instruments and their completion. Thus, after prior orientation, HADS-A was completed by the participant, while the instrument for sample characterization was applied by the researcher through an interview.

\section{Data AnAlysis}

Data was organized and stored in a database structured in Microsoft Excel ${ }^{\circledR}$. "Double entry" typing procedure was performed in order to validate it. Data were subsequently analyzed using the Statistical Package for Social Sciences (SPSS) program, version 17.0. Chi-square tests were performed for independence and Fisher's exact test was performed for homogeneity of categorical variables, while nonparametric statistics were found through the Shapiro-Wilk and Mann-Whitney tests for continuous variables, in addition to calculating the rank average. The significance level of $5 \%$ was considered in all statistical tests and the odds ratio was estimated with a $95 \%$ confidence interval for all study variables. Categorical variables were described as absolute and percentage numbers, and mean and standard deviation were also presented for the continuous variables. The relationships were considered statistically significant for $\mathrm{p} \leq 0.05$. After the univariate analysis, the variables that showed association with anxiety $(p \leq 0.05)$ were included in the logistic regression model. The internal consistency of the HADS-A subscale was analyzed by Cronbach's Alpha Coefficient.

\section{RESULTS}

A total of 209 pregnant women from a municipality in the south of Minas Gerais state participated. Sociodemographic characteristics of the study participants are described in Table 1.

The study participants were predominantly young women aged between 20 and 30 years (64.4\%), catholic (56.9\%) and married or in a stable relationship (94.3\%). Also, they had completed high school/secondary education (41.1\%) which corresponds to 12 years of studying, had a family income between one and three minimum wages $(45.5 \%)$, were living in their own residence $(65.6 \%)$ and had a professional occupation with paid activity (49.3\%).

Table 1 - Distribution of pregnant women according to sociodemographic characteristics - Alfenas, Minas Gerais, Brazil, 2015.

\begin{tabular}{|c|c|c|}
\hline Variables & $\mathbf{N}$ & $\%$ \\
\hline \multicolumn{3}{|l|}{ Age group (years) } \\
\hline$<20$ & 31 & 14.8 \\
\hline $20-30$ & 135 & 64.4 \\
\hline $31-40$ & 41 & 19.8 \\
\hline$>41$ & 2 & 1.0 \\
\hline \multicolumn{3}{|l|}{ Education level } \\
\hline Illiterate/No (formal) education & 1 & 0.5 \\
\hline Incomplete Primary Education & 43 & 20.6 \\
\hline Primary Education & 68 & 32.5 \\
\hline Secondary Education & 86 & 41.1 \\
\hline Higher Education & 11 & 5.3 \\
\hline \multicolumn{3}{|l|}{ Marital status } \\
\hline Single & 8 & 3.8 \\
\hline Married/Stable Relationship & 197 & 94.3 \\
\hline Divorced & 4 & 1.9 \\
\hline \multicolumn{3}{|l|}{ Religious Belief } \\
\hline Catholic & 119 & 56.9 \\
\hline Evangelical & 55 & 26.3 \\
\hline Other & 3 & 1.5 \\
\hline No religion & 32 & 15.3 \\
\hline \multicolumn{3}{|c|}{ Monthly family income (minimum wages) ${ }^{1}$} \\
\hline Up to 1 & 38 & 18.2 \\
\hline $1-3$ & 95 & 45.5 \\
\hline$>3$ & 22 & 10.5 \\
\hline Not reported & 54 & 25.8 \\
\hline \multicolumn{3}{|l|}{ Occupation } \\
\hline Housewife & 101 & 48.3 \\
\hline Paid work activity & 103 & 49.3 \\
\hline Student & 5 & 2.4 \\
\hline \multicolumn{3}{|l|}{ Housing } \\
\hline Owned & 137 & 65.6 \\
\hline Not owned & 72 & 34.4 \\
\hline
\end{tabular}

Regarding the reliability of the instrument in the studied sample as verified by the internal consistency of the subscale of anxiety in the measurement of Cronbach's alpha, it obtained a value of 0.76 . The referred value allowed for considering the scale's consistency as good and acceptable 
for the evaluated items, demonstrating correlation between them; thus evidencing the quality and reliability of the implemented instrument.

Regarding the results related to the variable of interest (the anxiety measure obtained by applying the HADS-A subscale), it was considered the possible intervals for the anxiety measure as ranging from zero to 21 , where a higher value indicates a greater chance of the individual developing an anxiety disorder. Thus, the interval obtained for the anxiety measure was between zero and 20 . The group mean for the anxiety measure was $5.63(\mathrm{SD} \pm 4.73)$.

Regarding the occurrence of anxiety disorder during pregnancy using the criterion suggested by the scale's ${ }^{(15)}$ authors, which determines a score of eight as the cut-off point for HADS-Anxiety, it was shown that $26.8 \%$ (56) of the pregnant women were affected by it, with higher rates in the third trimester (42.9\%), as shown in Table 2.

Table 2 - Distribution of pregnant women according to gestational age and the presence of anxiety - Alfenas, Minas Gerais, Brazil, 2015.

\begin{tabular}{lccc}
\hline Variable & No anxiety N (\%) & $\begin{array}{c}\text { Having anxiety } \\
\mathbf{N}(\%)\end{array}$ & P* \\
\hline Gestational age & & & \\
$1^{\text {st }}$ trimester & $34(22.2 \%)$ & $10(17.9 \%)$ & \\
$2^{\text {nd }}$ trimester & $60(39.2 \%)$ & $22(39.3 \%)$ & 0.755 \\
$3^{\text {rd }}$ trimester & $59(38.6 \%)$ & $24(42.9 \%)$ & \\
\hline Total & $\mathbf{1 5 3}(\mathbf{1 0 0} \%)$ & $\mathbf{5 6}(\mathbf{1 0 0} \%)$ & \\
\hline Note: ${ }^{*}=$ p value calculated by Pearson's Chi-square test.
\end{tabular}

Table 3 presents the variables that had a statistically significant association with the occurrence of anxiety during pregnancy.

The results of this Table indicate a statistically significant association between the presence of anxiety during pregnancy and occupation $(\mathrm{p}=0.04)$, evidencing that pregnant women who performed housewife activities had a greater chance of developing anxiety during pregnancy than those who were employed.

In this study, pregnant women who were in the third trimester of pregnancy predominated (39.7\%). Regarding obstetric history, 190 (90.9\%) participants had no difficulty in becoming pregnant, 199 (95.2\%) did not undergo treatment to get pregnant, and 140 (67\%) were multigestive. Among the multigestive women, complications in previous pregnancies were present in the obstetric history of $47.1 \%$, and the history of abortion/risk of preterm birth was experienced by $59(42.1 \%)$ of them, factors that were significantly associated with the occurrence of anxiety during pregnancy, being $\mathrm{p}=0.050$ and 0.007 , respectively (Table 3 ). Regarding the current gestation, $25.8 \%$ (54) were dealing with or experiencing obstetric complications, and 83 (39.7\%) had no children.

The vast majority of participants $(98.6 \%)$ in this study desired the gestation that they were experiencing, a feeling that was also experienced by $99 \%$ of the child's fathers. Maternal desire for gestation was associated with the occurrence of anxiety during pregnancy $(\mathrm{p}=0.018)$ (Table 3$)$. We also emphasize that $99 \%$ of the participants received support from family members and from the child's father during gestation.

Table 3 - Factors associated with anxiety among pregnant women - Alfenas, Minas Gerais, Brazil, 2015.

\begin{tabular}{|c|c|c|c|c|c|}
\hline Variable & No anxiety $\mathbf{N}(\%)$ & Having Anxiety N (\%) & $\mathbf{p}$ & OR & $95 \% \mathrm{Cl}$ \\
\hline \multicolumn{6}{|l|}{ Occupation } \\
\hline Performs paid activity & $69(67 \%)$ & $34(33 \%)$ & $0.046^{\mathrm{a} *}$ & 0.53 & \\
\hline Housewife & $84(79.2 \%)$ & $22(20.8 \%)$ & & 1.00 & $0.28-0.99$ \\
\hline \multicolumn{6}{|c|}{ Abortion/history risk of premature birth } \\
\hline Yes & $30(61.2 \%)$ & $29(38.8 \%)$ & $0.050^{\mathrm{a} *}$ & 2.11 & $0.99-4.48$ \\
\hline No & $70(76.9 \%)$ & $21(23.1 \%)$ & & 1.00 & \\
\hline \multicolumn{6}{|c|}{ Presence of complications in previous pregnancies } \\
\hline Yes & $40(60.6 \%)$ & $26(39.4 \%)$ & $0.007^{\mathrm{a} *}$ & 2.78 & $1.29-5.97$ \\
\hline No & $60(81.8 \%)$ & $14(18.2 \%)$ & & 1.00 & \\
\hline \multicolumn{6}{|c|}{ Maternal desire regarding the pregnancy } \\
\hline Yes & $153(74.3 \%)$ & $53(25.7 \%)$ & $0.018^{\mathrm{b} *}$ & $* *$ & \\
\hline No & $0(0 \%)$ & $3(100 \%)$ & & & \\
\hline \multicolumn{6}{|c|}{ Amount of cigarettes smoked per day } \\
\hline Up to 10 cigarettes & $14(93.3 \%)$ & $1(6.7 \%)$ & $0.004^{\mathrm{b} *}$ & 1.00 & \\
\hline More than 10 cigarettes & $3(33.3 \%)$ & $6(66.7 \%)$ & & 28.00 & $2.39-326.73$ \\
\hline \multicolumn{6}{|l|}{ Illicit drug use } \\
\hline Yes & $1(20 \%)$ & $4(80 \%)$ & $0.019^{b *}$ & 11.69 & $1.27-106.99$ \\
\hline No & $152(74.5 \%)$ & $52(25.5 \%)$ & & 1.00 & \\
\hline
\end{tabular}

Note: OR=Odds ratio; CI=Confidence Interval; a=Application of Pearson's Chi-square test; b=Application of Fisher's Exact Test; *Statistically significant difference for $\mathrm{P} \leq 0.05 ; * *$ Unable to calculate OR.

The number of miscarriages also showed a statistically significant relationship with the occurrence of anxiety during pregnancy (Table 4). Contrary to expected, an inverse relationship between the number of abortions and the presence of anxiety during pregnancy was found, so that pregnant women who had experienced more abortions in previous pregnancies (mean rank=22.60) showed no anxiety.
In this study, 185 (85.5\%) pregnant women reported not being smokers, 194 (92.8\%) did not consume alcohol and 204 (97.6\%) did not use illicit drugs. The latter variable was associated with anxiety during pregnancy $(\mathrm{p}=0.019)$, as well as the amount of cigarettes consumed per day $(\mathrm{p}=0.004)$. Thus, pregnant women who smoked more than 10 cigarettes a day and used illicit drugs were 28 and 11 times more likely 
to experience anxiety in pregnancy, respectively, than those who did not use either of these drugs (Table 3).

Table 4 - Mean ranks and $p$ values for the association between anxiety and number of miscarriages among participants - Alfenas, Minas Gerais, Brazil, 2015.

\begin{tabular}{cccc}
\hline \multirow{2}{*}{ Variable } & \multicolumn{2}{c}{ Mean ranks } & \multirow{2}{*}{$\mathrm{p}^{\mathrm{c}}$} \\
\cline { 2 - 3 } & No anxiety & $\begin{array}{l}\text { Having } \\
\text { anxiety }\end{array}$ & \\
\hline Number of abortions & 22.6 & 17.0 & $0.026^{*}$ \\
\hline
\end{tabular}

Note: ${ }^{c}=$ Application of the Mann-Whitney Test; ${ }^{*}$ Statistically significant difference for $\mathrm{P} \leq 0.05$

The main health problem reported by pregnant women, although infrequently (12\%), was systemic arterial hypertension with 10 (40\%). We also emphasize that 195 (90.7\%) participants did not use daily medication; however, among those who did, the most common drugs used were antihypertensive medication (42.8\%).

A history of pre-gestational mental disorder was reported by $42(20.1 \%)$ pregnant women. Among the pregnant women who experienced a disorder in the past, 25 (59.5\%) had undergone treatment, and pharmacological treatment was performed by 18 (72\%) participants.

It was also observed that 139 (66.5\%) pregnant women reported not having experienced a remarkable event in their life in the previous year. However, death (54.3\%) and the diagnosis of a disease (12.8\%) in loved ones were both the most frequent events reported by the participants who experienced it.

With regard to violence against women, 21 (10\%) pregnant women reported a history of domestic violence and only one reported experiencing it currently; with physical violence being the most suffered in the past $(71.4 \%)$, and psychological/moral violence being the most frequent at the present time (100\%).

Considering interpersonal relationships, the relationship with family, friends and close people was not satisfactory for $10.5 \%$ of pregnant women, and $12.7 \%$ of pregnant women were experiencing marital problems. However, $60.8 \%$ of the participants had social support, mainly provided by the family (88.9\%), which was mostly financial (74.8\%).

The following variables: occupation, complications in previous pregnancies, history of abortion/risk of preterm birth, maternal desire concerning pregnancy, number of abortions, number of cigarettes smoked per day and drug use were associated with the presence of anxiety during pregnancy $(\mathrm{p} \leq 0.05)$, and therefore were included in the logistic regression model. However, only the number of cigarettes consumed per day remained significantly associated with gestational anxiety, at a 5\% level in the final model, as described in Table 5 .

Table 5 - Logistic regression model: variable associated with anxiety among pregnant women - Alfenas, Minas Gerais, Brazil, 2015.

\begin{tabular}{lccccc}
\hline & Estimate & $\begin{array}{c}\text { Standard } \\
\text { error }\end{array}$ & $\mathbf{p}$ & OR & $\mathbf{9 5 \%} \mathbf{C I}$ \\
\hline $\begin{array}{l}\text { Number of } \\
\text { cigarettes }\end{array}$ & 3.332 & 1.254 & 0.008 & 28.000 & $\begin{array}{c}2.39- \\
\text { Constant }\end{array}$ \\
\multicolumn{2}{l}{ Note: OR=Odds ratio; CI=Confidence interval. }
\end{tabular}

\section{DISCUSSION}

The sociodemographic characteristics of women suffering from mental health symptoms and/or disorders may differ among them. Thus, the characterization of the participants of this study resembled that of other studies regarding age and marital status ${ }^{(4)}$, however it differs from other studies regarding income and educational level ${ }^{(6)}$.

Considering the incidence of anxiety during pregnancy, there are no homogeneous data. In the present study, $26.8 \%$ (56) of the pregnant women presented anxiety during pregnancy. In a study conducted in Pakistan ${ }^{(4)}$, which also used the Hospital Anxiety Subscale as an instrument to assess this disorder, the prevalence of anxiety among pregnant women was $20.4 \%$. Different data were found by a study carried out in South Africa, which used another instrument and found a rate of $11.8 \%$ of anxious pregnant women ${ }^{(17)}$.

The likely reasons for variation in rates can be attributed to differences in sample size and selection methods, as well as the tools used to assess anxiety. Moreover, it is important to note that the highest incidence found in the present study compared to studies that used other instruments can be explained by the fact that the Hospital Anxiety Subscale is self-administered, and as a result women probably did not feel influenced by the researcher and more openly expressed what they really felt.

Gestational age had no significant association with anxiety; however, it was more frequent in the last trimester of pregnancy. This finding is similar to that found by other researchers in studies conducted in Italy ${ }^{(3)}$ and in Australia ${ }^{(18)}$.

Higher anxiety rates in the third trimester of gestation may be related to the closeness to delivery, considering that the third trimester of gestation is particularly demanding for women due to this proximity ${ }^{(19)}$. This can be explained by the fact that pregnancy and childbirth are perceived by some pregnant women as moments of vulnerability, capable of triggering feelings of fear in women ${ }^{(20)}$, which can be present even in women who have experienced previous births, as was the case of the majority of the pregnant women in this study (67\%) who were multigestive. The feeling of fear can be exacerbated with the approaching moment of the child's birth, even though it is expected throughout gestation, thus predisposing the pregnant woman to changes in her psychological well-being, since the literature demonstrates that women who are afraid of childbirth may be at greater risk of developing anxiety during pregnancy ${ }^{(21)}$.

Similar to what is shown in the literature, in this study the risk of anxiety in pregnancy was higher among pregnant women who did not perform paid work activities ${ }^{(20)}$, highlighting employment as a protective factor for their mental health. This finding contrasts a Pakistani study, which showed that pregnant women working outside the household were more anxious and depressed than housewives who did not engage in labor activity ${ }^{(8)}$.

Several factors may elucidate the findings of this study. Among the aspects related to domestic work associated with female mental health, we emphasize that the monotony of the domestic routine along with the little possibility for 
change can be a determinant to the occurrence of mental disorders. Added to these findings is the fact that a lack of leisure and distraction predominant in the domestic routine can discourage many women, making them feel trapped, a fact that could contribute to the development of common mental disorders ${ }^{(22)}$ such as anxiety.

The presence of complications in previous pregnancies and the history of abortion/risk of preterm birth were also shown to be risk factors for anxiety during the prenatal period.

The findings of this research are supported by a review study on the risk factors for anxiety and depression during pregnancy with consequent implications for maternal health and well-being. According to that study, the association between the presence of prenatal anxiety and complications in previous pregnancies including the experience of an abortion/risk of preterm birth reflect how previous pregnancies impact women's experience in the ongoing pregnancy, so that the history of complications in past pregnancies invariably has a negative effect translated into accentuating anxiety levels in the present pregnancy ${ }^{(5)}$.

Regarding the woman's desire for pregnancy, it is relevant to mention that an unwanted pregnancy may contribute to psychological maladaptation, being responsible for developing anxiety during pregnancy, as demonstrated in another study ${ }^{(6)}$. In this context, there is evidence of an association between the maternal desire regarding pregnancy and the greater propensity to trigger emotional disturbances, such as feelings of anguish and unhappiness that, when associated with other factors, may represent potential triggers for developing mental disorders in pregnant women, giving an indication of the profound impact of an unwanted pregnancy on women's mental health.

It should be noted that in countries with limited socioeconomic contexts, such as Ethiopia, the maternal desire for pregnancy may be closely related to family income, since in the context of a pregnancy it is expected to increase expenses due to the growth of the family. Thus, situations of insecurity and stress can be exacerbated, compromising the well-being of the pregnant woman. Similar to the Ethiopian study, the present study did not show an association between family income and the occurrence of anxiety in pregnancy, despite the socioeconomic differences between the two countries.

A study conducted in Cape Town, South Africa with pregnant women who have anxiety or depression disorder found that undesired pregnancy is a risk factor for mental disorders, both during prenatal and postpartum periods ${ }^{(17)}$.

The present study also evidenced the association between number of abortions and anxiety during pregnancy, however, contrary to the expectations, an inverse relationship between them was observed, so that pregnant women who had more abortions in previous pregnancies did not present anxiety. This result contrasts the findings of another study in which the history of abortions was significantly associated with anxiety and common mental disorders in pregnancy ${ }^{(8)}$.

A possible explanation for controversial and unexpected findings such as what was found in this study would be the socio-cultural configuration of the society in which the studied sample is inserted. Thus, some variables can act as stressors in an investigated population and not in another. In these situations, it is also important to reaffirm the importance of considering the complexity of the phenomenon being studied, considering the effect of other variables on the development of anxiety during pregnancy.

Another important finding of the present study demonstrates that the amount of cigarettes consumed per day and illicit drug use are factors associated with anxiety during pregnancy.

These results are consistent with the findings of other researchers that smoking, as well as other depression symptoms, are associated with higher anxiety symptoms ${ }^{(23)}$.

Regarding our finding in the present study, the higher number of cigarettes consumed per day by pregnant women may be a consequence of the anxiety triggered in pregnancy by nicotine, and also by the changes and situations that generate stress, typical of the period.

Despite the association between the number of cigarettes consumed per day by the pregnant women and the development of anxiety during pregnancy, our study was not able to establish a relationship of causality since this is a cross-sectional study, therefore it is not possible to infer whether it was the anxiety developed during gestation that contributed to the greater consumption of cigarettes per day or the opposite.

In this context, it is important to emphasize the importance of the obstetrical nursing team working with the pregnant smoker, considering prenatal care as an opportune moment for developing health promotion actions that aim at accomplishing the appropriate treatment for stopping the addiction and preventing smoking dependence.

With regard to illicit drug use, although it is expected that during pregnancy a woman will acquire behaviors that contribute to her health and that of her unborn child, continuing deviant behaviors such as the use of alcohol and drugs is a reality among many pregnant women. In this sense, developing anxiety may be associated with the mechanisms that drug use triggers in the body of the users.

On the other hand, it is also possible that factors related to pregnancy itself such as the changes inherent to this period contribute to developing anxiety, and that this condition motivates drug consumption among pregnant women, since anxiety represents a comorbidity and a risk factor for substance abuse ${ }^{(24)}$.

A study on the prevalence and factors associated with illicit drug use during pregnancy found that pregnant women with moderate to severe anxiety levels were twice as likely to use drugs throughout the pregnancy ${ }^{(24)}$.

The present study presents its transversal design as a limitation, thereby not allowing inferences to be made about the temporal relation of the events or on the relationship between cause and effect of the results found.

\section{CONCLUSION}

Anxiety has been shown to be a frequent mental disorder among pregnant women, being more present in the third trimester of gestation, and its occurrence is associated with the pregnant woman's occupation, history of abortion, presence 
of complications in previous pregnancies, maternal desire regarding the pregnancy, number of cigarettes consumed per day and the use of illicit drugs.

Regarding the implemented instrument, application of the HADS-A anxiety subscale among pregnant women brings an important contribution to nursing, in addition to broadening the use of this instrument.

Considering the adverse obstetric outcomes and the serious consequences to maternal and fetal health associated with the occurrence of anxiety during pregnancy and its underdiagnosis in this period, the results of this study are extremely important. Understanding the factors associated with its occurrence allows for elaborating preventive prenatal care measures, which is characterized as an opportune space for developing interventions aimed at promoting the mental health of pregnant women; moreover, the integrated and coordinated action of the multidisciplinary and interdisciplinary team, since attaining favorable physical and mental well-being depends on interventions in all dimensions involving the holistic being.

\section{RESUMO}

Objetivo: Avaliar a ocorrência da ansiedade em gestantes e os fatores associados à sua ocorrência; comparar a presença de ansiedade em cada trimestre gestacional. Método: Estudo descritivo, correlacional, de corte transversal. A coleta de dados ocorreu de janeiro a maio de 2013, utilizou-se da Subescala Hospitalar de Ansiedade e de um formulário composto por caracterização socioeconômica; anamnese gestacional; hábitos e eventos marcantes de vida; patologias preexistentes e relacionamentos interpessoais. Resultados: Participaram do estudo 209 gestantes de um município do sul de Minas Gerais. A ansiedade esteve presente em 26,8\% das gestantes, sendo mais frequente no terceiro trimestre $(42,9 \%)$. Ocupação $(p=0,04)$, complicações em gestações anteriores $(p=0,00)$, histórico de abortamento/ ameaça de parto prematuro $(\mathrm{p}=0,05)$, desejo materno em relação à gravidez $(\mathrm{p}=0,01)$, número de abortamentos $(\mathrm{p}=0,02)$, quantidade de cigarros consumidos diariamente $(\mathrm{p}=0,00)$ e uso de drogas $(\mathrm{p}=0,01)$ apresentaram associação estatisticamente significativa com a ocorrência da ansiedade na gravidez. Conclusão: A ansiedade se mostrou frequente na gestação. O conhecimento dos fatores associados a sua ocorrência oportuniza a elaboração de medidas preventivas na assistência pré-natal.

\section{DESCRITORES}

Gravidez; Ansiedade; Fatores de Risco; Enfermagem Obstétrica; Cuidado Pré-Natal.

\section{RESUMEN}

Objetivo: Evaluar la ocurrencia de la ansiedad en embarazadas y los factores asociados con su ocurrencia; comparar la presencia de ansiedad en cada trimestre gestacional. Método: Estudio descriptivo, correlacional, de corte transversal. La recolección de datos ocurrió de enero a mayo de 2013, se utilizó la Subescala Hospitalaria de Ansiedad y un formulario compuesto de caracterización socioeconómica; anamnesis gestacional; hábitos y eventos determinantes de vida; patologías y relaciones interpersonales. Resultados: Participaron en el estudio 209 embarazadas de un municipio del sur de Minas Gerais. La ansiedad estuvo presente en el 26,8\% de las embarazadas, siendo más frecuente en el tercer trimestre $(42,9 \%)$. Ocupación $(p=0,04)$, complicaciones en embarazos anteriores $(p=0,00)$, historia de aborto/amenaza de parto prematuro $(\mathrm{p}=0,05)$, deseo materno con relación al embarazo $(\mathrm{p}=0,01)$, número de abortos $(\mathrm{p}=0,02)$, cantidad de cigarrillos consumidos diariamente $(\mathrm{p}=0,00)$ y drogadicción $(\mathrm{p}=0,01)$ presentaron asociación estadísticamente significativa con la ocurrencia de la ansiedad en el embarazo. Conclusión: La ansiedad se mostró frecuente en el embarazo. El conocimiento de los factores asociados con su ocurrencia facilita la elaboración de medidas preventivas en la asistencia pre natal.

\section{DESCRIPTORES}

Embarazo; Ansiedad; Factores de Riesgo; Enfermería Obstétrica; Atención Prenatal.

\section{REFERENCES}

1. Din ZU, Ambreen S, Iqbal Z, Iqbal M, Ahmad S. Determinants of antenatal psychological distress in Pakistani women. Noro Psikiyatr Ars [Internet]. 2016 [cited 2017 Apr 04];53(2):152-7. Available from: https:/www.ncbi.nlm.nih.gov/pmc/articles/PMC5353020/

2. Yuksel F, Akin S, Durna Z. Prenatal distress in Turkish pregnant women and factors associated with maternal prenatal distress. J Clin Nurs. 2014;23(1-2):54-64.

3. Giardinelli L, Innocenti A, Benni L, Stefanini MC, Lino G, Lunardi C, et al. Depression and anxiety in perinatal period: prevalence and risk factors in an Italian sample. Arch Womens Ment Health. 2012;15(1):21-30.

4. Ali NS, Azam IS, Ali BS, Tabbusum G, Moin SS. Frequency and associated factors for anxiety and depression in pregnant women: a hospitalbased cross-sectional study. Scientific World J [Internet]. 2012 [cited 2013 Oct 15];2012:653098. Available from: https://www.hindawi. com/journals/tswj/2012/653098/

5. Biaggi A, Conroy S, Pawlby S, Pariante CM. Identifying the women at risk of antenatal anxiety and depression: a systematic review. J Affect Disord [Internet]. 2016 [cited 2017 Feb 2];191:62-77. Available from: https://www.ncbi.nlm.nih.gov/pubmed/26650969

6. Bayrampour H, McDonald S, Tough S. Risk factors of transient and persistent anxiety during pregnancy. Midwifery. 2015;31(6):582-9.

7. Martini J, Petzoldt J, Einsle F, Beesdo-Baum K, Hofler M, Wittchen HU. Risk factors and course patterns of anxiety and depressive disorders during pregnancy and after delivery: a prospective-longitudinal study. J Affect Disord [Internet]. 2015 [cited 2017 Jan 30];175:385-95. Available from: http://www.sciencedirect.com/science/article/pii/S0165032715000166

8. Waqas A, Raza N, Lodhi HW, Muhammad Z, Jamal M, Rehman A. Psychosocial factors of antenatal anxiety and depression in Pakistan: is social support a mediator? PLoS One [Internet]. 2015 [cited 2017 Jan 29];10:e0116510. Available from: http://journals.plos.org/plosone/ article?id=10.1371/journal.pone.0116510 
9. Norhayati MN, Hazlina NH, Asrenee AR, Emilin WM. Magnitude and risk factors for postpartum symptoms: a literature review. J Affect Disord [Internet]. 2015 [cited 2017 Feb 4];175:34-52. Available from: http://www.sciencedirect.com/science/article/pii/S0165032714008271

10. Chojenta C, Harris S, Reilly N, Forder P, Austin MP, Loxton D. History of pregnancy loss increases the risk of mental health problems in subsequent pregnancies but not in the postpartum. PLoS One [Internet]. 2014 [cited 2017 Feb 2];9(4):e95038. Available from: https:// www.ncbi.nlm.nih.gov/pmc/articles/PMC3986356/

11. Rubertsson C, Hellstrom J, Cross M, Sydsjo G. Anxiety in early pregnancy: prevalence and contributing factors. Arch Womens Ment Health [Internet]. 2014 [cited 2017 Jan 28]; 17(3):221-8.Available from: https://link.springer.com/article/10.1007\%2Fs00737-013-0409-0

12. Ding XX, Wu YL, Xu SJ, Zhu RP, Jia XM, Zhang SF, et al. Maternal anxiety during pregnancy and adverse birth outcomes: A systematic review and meta-analysis of prospective cohort studies. J Affect Disord [Internet]. 2014 [cited 2017 Jan 3];159:103-10. Available from: http://www.sciencedirect.com/science/article/pii/S0165032714000731

13. Betts KS, Williams GM, Najman JM, Alati R. The relationship between maternal depressive, anxious, and stress symptoms during pregnancy and adult offspring behavioral and emotional problems. Depress Anxiety. 2015;32(2):82-90.

14. Botega NJ, Ponde MP, Medeiros P, Lima MG, Guerreiro CAM. Validação da escala hospitalar de ansiedade e depressão (HAD) em pacientes epilépticos ambulatoriais. J Bras Psiq.199;47(6):285-9.

15. Silva MMJ, Leite EPRC, Nogueira DA, Clapis MJ. Depression in pregnancy: prevalence and associated factors. Invest Educ Enferm [Internet]. 2016 [cited 2017 Apr 05];34(2):342-50. Available from: http://www.scielo.org.co/pdf/iee/v34n2/v34n2a14.pdf

16. Zigmond AS, Snaith RP. The hospital anxiety and depression scale. Acta Psychiatr Scand. 1983;67(6):361-70.

17. Vythilingum B, Campo S, Kafaar Z, Baron E, Stein DJ, Sanders L, et al. Screening and pathways to maternal mental health care in a South African antenatal setting. Arch Womens Ment Health [Internet]. 2013 [cited 2013 Oct 20];16(1):371-9. Available from: https://link.springer. com/article/10.1007\%2Fs00737-013-0343-1

18. Rallis S, Skouteris H, McCabe M, Milgrom J A prospective examination of depression, anxiety and stress throughout pregnancy. Women Birth [Internet]. 2014 [cited 2017 Jan 29];27(4):e36-e42. Available from: http://www.sciencedirect.com/science/article/pii/S1871519214000821

19. Souza MG, Vieira BDG, Alves VH, Rodrigues DP, Leão DCMR, De Sá AMP. Concern of primiparous women with regard to labor and birth. J Res Fundam Care. Online [Internet]. 2015 [cited 2017 Apr 02];7(1):1987-2000. Available from: http://www.seer.unirio.br/index.php/ cuidadofundamental/article/view/3504/pdf_1441

20. Gourounti K, Anagnostopoulos F, Lykeridou K. Coping strategies as psychological risk factor for antenatal anxiety, worries, and depression among Greek women. Arch Womens Ment Health [Internet]. 2013 [cited 2013 Oct 17];16(5):353-61. Available from: http://link.springer. com/article/10.1007\%2Fs00737-013-0338-y

21. Cetişli NE, Zirek ZD, Abali FB. Childbirth and postpartum period fear in pregnant women and the affecting factors. Aquichan [Internet]. 2016 [cited 2017 Apr 03];16(1):32-42. Available from: http://www.scielo.org.co/pdf/aqui/v16n1/v16n1a05.pdf

22. Pinho OS, Araújo TM. Association between housework overload and common mental disorders in women. Rev Bras Epidemiol [Internet]. 2012 [cited 2017 Mar 31];15(3): 560-72. Available from: http://www.scielo.br/pdf/rbepid/v15n3/en_10.pdf

23. Lee JY, Brook JS, Finch SJ, Rosa M, Brook DW. Joint trajectories of cigarette smoking and depressive symptoms from the mid-twenties to the mid-20s to the mid-30s predicting generalized anxiety disorder. J Addict Dis. 2017 Mar 10. [Epub ahead of print]

24. Rocha PC, Britto e Alves MTSS, Chagas DC, Silva AAM, Batista RFL, Silva RA. Prevalência e fatores associados ao uso de drogas ilícitas em gestantes da coorte BRISA. Cad Saúde Pública [Internet]. 2016 [citado 2017 abr. 04];32(1):e00192714. Disponível em: http://www. scielo.br/pdf/csp/v32n1/0102-311X-csp-0102-311X00192714.pdf 